\title{
Molecular detection of Dirofilaria spp. and host blood-meal identification in the Simulium turgaicum complex (Diptera: Simuliidae) in the Aras River Basin, northwestern Iran
}

Fariba Khanzadeh', Samad Khaghaninia', Naseh Maleki-Ravasan²,3*, Mona Koosha ${ }^{4}$ and Mohammad Ali Oshaghi* ${ }^{*}$

\begin{abstract}
Background: Blackflies (Diptera: Simuliidae) are known as effective vectors of human and animal pathogens, worldwide. We have already indicated that some individuals in the Simulium turgaicum complex are annoying pests of humans and livestock in the Aras River Basin, Iran. However, there is no evidence of host preference and their possible vectorial role in the region. This study was conducted to capture the S. turgaicum (s.l.), to identify their host bloodmeals, and to examine their potential involvement in the circulation of zoonotic microfilariae in the study areas.

Methods: Adult blackflies of the S. turgaicum complex were bimonthly trapped with insect net in four ecotopes (humans/animals outdoors, irrigation canals, lands along the river, as well as rice and alfalfa farms) of ten villages (Gholibaiglou, Gungormaz, Hamrahlou, Hasanlou, Khetay, Khomarlou, Larijan, Mohammad Salehlou, Parvizkhanlou and Qarloujeh) of the Aras River Basin. A highly sensitive and specific nested PCR assay was used for detection of filarial nematodes in S. turgaicum (s.l.), using nuclear 18 S rDNA-ITS1 markers. The sources of blood meals of engorged specimens were determined using multiplex and conventional cytb PCR assays.
\end{abstract}

Results: A total of 2754 females of S. turgaicum (s.l.) were collected. The DNA of filarial parasites was detected in 6 $(0.62 \%)$ of 960 randomly examined individuals. Sequence analysis of 420 base pairs of 185 rDNA-ITS1 genes identified Dirofilaria spp. including 5 D. immitis and 1 D. repens. Importantly, all filarial positive specimens have been captured from humans and animals outdoors. Cytb-PCR assays showed that in all ecotypes studied, members of the S. turgaicum complex had preferably fed on humans, dogs, bovids, and birds, respectively.

Conclusions: To the best of our knowledge, this is the first report of D. immitis/D. repens detection in blackflies. Results showed that S. turgaicum (s.l.) was the most abundant (97\%) and anthropophilic (45\%) blackfly in all studied ecotypes/villages and that DNA of Dirofilaria spp. was detected in the flies taken from six villages. Dirofilariasis is a

\footnotetext{
*Correspondence: naseh_maleki@yahoo.com; moshaghi@tums.ac.ir

${ }^{2}$ Department of Parasitology, Pasteur Institute of Iran, Tehran, Iran

${ }^{4}$ Department of Medical Entomology and Vector Control, School

of Public Health, Tehran University of Medical Sciences (TUMS), Tehran,

Iran

Full list of author information is available at the end of the article
}

(c) The Author(s) 2020. This article is licensed under a Creative Commons Attribution 4.0 International License, which permits use, sharing, adaptation, distribution and reproduction in any medium or format, as long as you give appropriate credit to the original author(s) and the source, provide a link to the Creative Commons licence, and indicate if changes were made. The images or other third party material in this article are included in the article's Creative Commons licence, unless indicated otherwise in a credit line to the material. If material is not included in the article's Creative Commons licence and your intended use is not permitted by statutory regulation or exceeds the permitted use, you will need to obtain permission directly from the copyright holder. To view a copy of this licence, visit http://creativeco mmons.org/licenses/by/4.0/. The Creative Commons Public Domain Dedication waiver (http://creativecommons.org/publicdomain/ zero/1.0/) applies to the data made available in this article, unless otherwise stated in a credit line to the data. 
common zoonosis between humans and carnivores, with mosquitoes (Culicidae) as the principal vectors. Further investigations are needed to demonstrate that blackflies are actual vectors of Dirofilaria in the studied region.

Keywords: Simulium turgaicum complex, Vector incrimination, Dirofilaria immitis, D. repens, Blood meal

\section{Background}

Blackflies, buffalo gnats or turkey gnats (Diptera: Simuliidae) are known to be effective vectors among arthropod groups since they are vigorous in circulation of 28 vertebrate pathogens and parasites, besides the causal agent of human onchocerciasis is vectored by 25 Simulium spp. $[1,2]$. Potentially they are responsible for transmitting pathogenic agents ranging from protozoan parasites $(n=$ $17)$ to filarial nematodes $(n=15)$ and several arboviruses among numerous hosts [2]. In this spectrum, only two human diseases, onchocerciasis and mansonellosis, are caused by simuliid-borne filarial nematodes [1].

Onchocerciasis is caused by the parasitic worm Onchocerca volvulus and may lead to itching, disfiguring dermatitis, and eye lesions, including permanent blindness in humans. Although most infected people reside in Africa south of the Sahara, the disease is widespread to some areas in Latin America and Yemen, as well. Estimates in 2017 exposed that there were 21 million $\mathrm{O}$. volvulus infections worldwide; 14.6 million of the infected people with skin disease and 1.15 million with vision loss [3].

The pathology of mansonellosis, caused by Mansonella ozzardi, appears to be mild [4]. The disease is restricted to the New World tropics where the disease is vectored via at least five simuliid species and biting midges of the genus Culicoides [5].

In addition to being proficient vectors of important disease agents, blackflies are annoying pests of humans and animals due to their swarming and long-term bloodsucking behaviors resulting in significant economic losses in sectors of society from agriculture, animal husbandry, and forestry to tourism, and entertainment [6-10]. These flies are among the few arthropods that have the potential to kill animals by their extreme blood-feeding and serious toxemia (simuliotoxicosis) originated from the saliva $[11,12]$.

According to the last inventory of blackflies, a total of 2348 species including 2331 living and 17 fossil have been recorded as valid species worldwide [13]. The Palaearctic Region covers the most described blackflies species, with $33 \%$, followed by the Oriental (17\%), and Neotropical (16\%) Regions [13]. The Palaearctic Simulium subgenus Wilhelmia comprises 31 living species throughout Europe, Asia and Africa that are acknowledged as noteworthy and dominant pests of humans and livestock [8, 9, 14-17].
Simulium turgaicum is a species complex in the $S$. equinum species-group in the subgenus Wilhelmia. We recently showed with detailed morphological and molecular studies that $S$. turgaicum comprises three wellsupported lineages in Iran [9]. The divergence within $S$. turgaicum has previously been shown by other researchers, as well [16-18].

Simuliids are reported to be the most insidious insects in the Aras River Basin, so that farmers and ranchers have had to wear beekeeping hats or alter their working hours from day to night. In this region, blackflies enter farmers' eyes, ears, mouth, and nose throughout the day. However, in the late hours of the day and in crowded places, blackflies fly recklessly against all parts of humans and animals (our personal observations). The S. turgaicum complex dominates the blackfly community in the Aras River Basin, accounting for $97 \%$ of the specimens in our previous study [9].

There is little knowledge of the potential vectorial role of blackflies in Iran where no documentation exists on their role in the circulation of anthroponotic or zoonotic pathogens in the country. Although to date Simulium spp. have been described as vectors of Dirofilaria ursi, a parasite of American and Asian bears [19], to the best of our knowledge, no studies have been carried out regarding blackflies as vectors of mosaic zoonoses of $D$. immitis/D. repens. This study aimed to (i) determine the abundance of $S$. turgaicum complex in the Aras River basin of Iran, (ii) identify their host blood meals through PCR assays, and (iii) examine the potential involvement of the S. turgaicum complex in the circulation of zoonotic microfilariae in the region.

\section{Methods}

\section{Study area, blackfly collection and identification}

The study was conducted in the south of the Aras River, in Khoda-Afarin County, East Azarbaijan Province, in northwestern Iran. Due to the climatic conditions, water resources are abundant in this region so that the main occupations of the population are farming and animal husbandry. Adult blackflies were bimonthly trapped with a conventional insect net in four ecotopes (humans/animals outdoors, irrigation canals, lands along the Aras River, and rice and alfalfa fields) of 10 villages (Gholibaiglou, Gungormaz, Hamrahlou, Hasanlou, Khetay, Khomarlou, Larijan, Mohammad Salehlou, Parvizkhanlou and Qarloujeh) from May to October 2016-2018. 
Specimens were stored in $70 \%$ ethanol at $4{ }^{\circ} \mathrm{C}$ until investigation. Morphological identifications of the specimens were achieved using the key by Crosskey [20]. The specimens with empty and blood-fed abdomens were applied for filarial and mammalian hosts' genome analysis, respectively.

\section{DNA extraction, filarial species detection and sequencing}

A subset (31-71\%) of the specimens with empty abdomen (unfed or fully gravid) from each site was selected for filarial genome analysis. The selected specimens included representatives of all the blackflies caught per time and per net in the analysis. Adult blackflies were separately rinsed twice with $70 \%$ ethanol at $10,000 \times$ rpm for $2 \mathrm{~min}$. The whole bodies of dehydrated flies were pulverized using narrow metal pestles in $1.5 \mathrm{ml}$ microtubes. The total genomic DNA was extracted using the Collins et al. [21] method. A highly sensitive and specific nested PCR assay developed by Tang et al. [22] was applied for detection of potential filarial nematodes in blackflies using nuclear $18 S$ rDNA-ITS1 markers. These primers could amplify conserved regions of filarial 18S, 5.8S rDNA, and ITS1 from O. volvulus, Wuchereria bancrofti, Loa loa, Mansonella ozzardi, $M$. perstans, M. streptocerca, Brugia malayi, B. timori, and Dirofilaria spp.

Originally, primers of UNI-1R: 5'-CGC AGC TAG CTG CGT TCT TCA TCG-3' and FIL-1F: 5'-GTG CTG TAA CCA TTA CCG AAA GG-3' were applied to amplify a 712-771 bp of a partial sequence of the target loci. The PCR product of the first step was used as a template for the second step. In this step, the primers of FIL-2F: 5'-GGT GAA CCT GCG GAA GGA TC-3' and FIL-2R: 5'-TGC TTA TTA AGT CTA CTT AA-3' were used to amplify a $286-420 \mathrm{bp}$ fragment. The PCR was performed in a total volume of $25 \mu \mathrm{l}$ containing $5 \mu \mathrm{l}(\sim 0.5$ $\mu \mathrm{g})$ of genomic DNA for the first step of nested PCR, and $2.5 \mu \mathrm{l}$ of PCR product for the second step, $12.5 \mu \mathrm{l}$ of Taq DNA polymerase $2 \times$ master mix red (Ampliqon, Odense, Denmark), and $1 \mu \mathrm{l}$ of each primer $(10 \mathrm{mM})$, which was supplemented by double distilled water, in an automated Thermocycler (Analytik Jena FlexCycler; Midland, Ontario, Canada).

The PCR conditions were set as an initial denaturation at $94{ }^{\circ} \mathrm{C}$ for $7 \mathrm{~min}$, followed by (nest-one) 40 cycles of denaturation at $94{ }^{\circ} \mathrm{C}$ for $20 \mathrm{~s}$, annealing at $60{ }^{\circ} \mathrm{C}$ for 20 $\mathrm{s}$, and extension at $72{ }^{\circ} \mathrm{C}$ for $30 \mathrm{~s}$, or (nest-two) 35 cycles of denaturation at $94{ }^{\circ} \mathrm{C}$ for $20 \mathrm{~s}$, annealing at $50^{\circ} \mathrm{C}$ for 20 $\mathrm{s}$, and extension at $72{ }^{\circ} \mathrm{C}$ for $20 \mathrm{~s}$ with a final extension at $72{ }^{\circ} \mathrm{C}$ for $7 \mathrm{~min}$. PCR products were visualized with $1 \%$ agarose gel electrophoresis, followed by GreenViewer staining and imaging, using a UV transilluminator. Fruitful amplicons were sequenced in both directions via
Genetic Codon Company (Tehran, Iran), using the same primers as for amplification.

The respective sequences of 6 specimens are deposited in GenBank. Twenty-two reference sequences belonging to various nematodes were retrieved from GenBank and used for multiple sequence alignment and relationship inference by MEGA X [23].

\section{Blood-meal analysis of blackflies}

Two multiplex and conventional cytb-PCR methods were employed to investigate host use by the blackflies, according to the protocol modified from Lahiff et al. [24], Parodi et al. [25], Ngo \& Kramer [26], and Chang et al. [27]. Based on our preliminary study and knowledge of the animal species in the study area, 4 sets of primers (avian, bovine, dog and human) were used to determine the source of blood meals. Genomic DNA from blood-fed female blackflies was extracted using the Collins et al. [21] method. DNA from dog, bovine, hen, and human blood was set as positive controls, and DNA of male blackflies, as well as water, was used as negative controls. Reagents in the multiplex PCR assay were the same as those for the filarial detection; however, the thermal conditions for initial denaturation were at $94{ }^{\circ} \mathrm{C}$ for $10 \mathrm{~min}$, continued by 35 cycles of denaturation at $95{ }^{\circ} \mathrm{C}$ for $30 \mathrm{~s}$, annealing at $53{ }^{\circ} \mathrm{C}$ for $40 \mathrm{~s}$, and extension at $72{ }^{\circ} \mathrm{C}$ for $30 \mathrm{~s}$, followed by a final extension at $72{ }^{\circ} \mathrm{C}$ for $8 \mathrm{~min}$. The specific PCR for each avian, bovine, dog, and human host corresponded with annealing temperatures of $55^{\circ} \mathrm{C}, 58{ }^{\circ} \mathrm{C}, 56{ }^{\circ} \mathrm{C}$ and $64{ }^{\circ} \mathrm{C}$, respectively. PCR products from the two types of assays were analyzed by $2 \%$ agarose gel electrophoresis stained by GreenViewer dye (Parstous, Mashhad, Iran) and photographed on a UV transilluminator.

\section{Results}

\section{Entomological and parasitological findings}

Large numbers of blackflies were captured from the study areas, of which $97 \%$ including 2754 females and 300 males were morphologically identified as the Simulium turgaicum complex. Representative specimens of each ecotope in each village were selected for detection of filarial nematodes in S. turgaicum (s.l.) The DNA of filarial parasites was detected in $6(0.62 \%)$ of 960 individuals (Table 1). Importantly, all filarial positive specimens have been captured from humans and animals outdoors. Amplicons from the positive specimens were purified and sequenced. Sequence analysis of $\sim 420 \mathrm{bp}$ of $18 S \mathrm{rDNA}$ and ITS1 regions identified Dirofilaria spp. including $5 \mathrm{D}$. immitis and $1 \mathrm{D}$. repens. Five sequences of D. immitis (MT052018, MT052020-23) showed 99.05$100 \%$ identity with the isolates reported from Thailand (MK250772, MK250801, MK250802). A sequence of $D$. 
repens (MT052019) displayed 99.47\% similarity with a sequence reported from Thailand (AY621481). Relationships analysis using $18 S$ rDNA and ITS1 sequences confirmed that the specimen clustered with the Dirofilaria spp. lineage, with high bootstrap values (Fig. 1).

\section{Vertebrate hosts}

The sources of the blood meals were determined for 113 blood-fed specimens of the $S$. turgaicum complex trapped from different ecotypes of five villages, i.e. Gholibaiglou, Gungormaz, Hamrahlou, Khetay and Qarloujeh, in the Aras River Basin. Although blood-fed flies were present in all ecotopes studied, most of them were trapped from humans/animals outdoors, an epidemiologically important ecotope. Selected primers for avian, bovine, dog, and human hosts yielded 508, 271, 153, and 228 bp products, respectively, in both multiplex and specific cytb-PCR assays. Multiplex PCR results revealed four patterns of single $(n=14)$, double $(n=23)$, triple $(n=8)$ and quadruple $(n=1)$ blood sources among 46 specimens of $S$. turgaicum (s.l.) The method revealed blood-meal sources as human (45\%), dog (24\%), bovine (22\%), and bird (9\%). Nine out of 46 (19.6\%) specimens had at least mixed dog and human blood. Among the 113 blood-fed specimens tested by conventional PCR, 50 (44\%) fed on humans, 26 (23\%) on bovids, 22 (20\%) on dogs, and $15(13 \%)$ on birds
(Table 2). Feeding on humans varied among the populations of S. turgaicum (s.l.), from $30 \%$ to $51 \%$.

\section{Discussion}

Blackflies have been the focus of many studies since they are strong blood-feeders and competent vectors of human and animal disease agents. However, to date, they have not been implicated in the infection and possible transmission of D. immitis or D. repens. We found a high prevalence of S. turgaicum (s.l.) in the region, with blood meals primarily from humans and dogs, and with DNA of the microfilariae of both species in the specimens with empty abdomens which are unfed or fully gravid. Detection of filarial DNA in blackflies with empty abdomens indicates considerable age or survival which is epidemiologically thought-provoking indicating that the parasite is still present following the blood-digestion process and may evolve to its infective stage. The second point should be confirmed in future studies by confirming the vitality of the nematodes or the developmental stages of the microfilariae in the epidemiologically important parts of the fly's body.

Dirofilariasis is largely caused by two parasites, $D$. (Dirofilaria) immitis (Leidy, 1856) and D. (Nochtiella) repens (Railliet \& Henry, 1911) (Spirurida: Onchocercidae), in humans and carnivores, with distinct clinical and

Table 1 Females of Simulium turgaicum complex captured in Aras River Basin, Iran, and tested for Dirofilaria spp. infection

\begin{tabular}{|c|c|c|c|c|c|c|}
\hline Village & Ecotope $(n)$ & $\begin{array}{l}\text { No. of } \\
\text { collected } \\
\text { specimens }\end{array}$ & $\begin{array}{l}\text { No. of specimens } \\
\text { used for filer } \\
\text { detection (\%) }\end{array}$ & No. of infected (\%) & Dirofilaria species & GenBank ID \\
\hline Deim-Qarloujeh & Irrigation canals in rural areas $(n=513)$ & 513 & $220(43)$ & $1(0.45)$ & D. repens & MT052019 \\
\hline Gholibaiglou & $\begin{array}{l}\text { Lands along the Aras River }(n=57) \text {, rice } \\
\text { and alfalfa fields }(n=43)\end{array}$ & 100 & $40(40)$ & - & - & - \\
\hline Gungormaz & $\begin{array}{l}\text { Lands along the Aras River }(n=75) \text {, } \\
\text { humans and animals outdoors }(n= \\
\text { 105) }\end{array}$ & 180 & $60(33)$ & $1(1.67)$ & D. immitis & MT052020 \\
\hline Hamrahlou & $\begin{array}{l}\text { Lands along the Aras River }(n=178) \text {, } \\
\text { humans and animals outdoors }(n= \\
\text { 142) }\end{array}$ & 320 & $100(31)$ & - & - & - \\
\hline Hasanlou & $\begin{array}{l}\text { Lands along the Aras River }(n=18) \text {, rice } \\
\text { and alfalfa fields }(n=7)\end{array}$ & 25 & $10(40)$ & - & - & - \\
\hline Khetay & $\begin{array}{l}\text { Humans and animals outdoors }(n= \\
\text { 396) }\end{array}$ & 396 & $110(28)$ & $1(0.91)$ & D. immitis & MT052023 \\
\hline Khomarlou & Lands along the Aras River $(n=142)$ & 142 & $50(35)$ & $1(2)$ & D. immitis & MT052018 \\
\hline Larijan & $\begin{array}{l}\text { Lands along the Aras River }(n=72) \text {, } \\
\text { humans and animals outdoors }(n= \\
\text { 33) }\end{array}$ & 105 & $50(48)$ & $1(2)$ & D. immitis & MT052021 \\
\hline Parvizkhanlou & Alfalfa field $(n=42)$ & 42 & $30(71)$ & - & - & - \\
\hline Qarloujeh & $\begin{array}{l}\text { Rice and alfalfa fields }(n=453) \text {, humans } \\
\text { and animals outdoors }(n=478)\end{array}$ & 931 & $290(31)$ & $1(0.34)$ & D. immitis & MT052022 \\
\hline Total & & 2754 & $960(35)$ & $6(0.625)$ & - & - \\
\hline
\end{tabular}

Note: The data on the males of S. turgaicum (s.I.) and the remaining $3 \%$ collected blackflies are not shown here

Abbreviation: $\mathrm{n}$, total number of specimens 


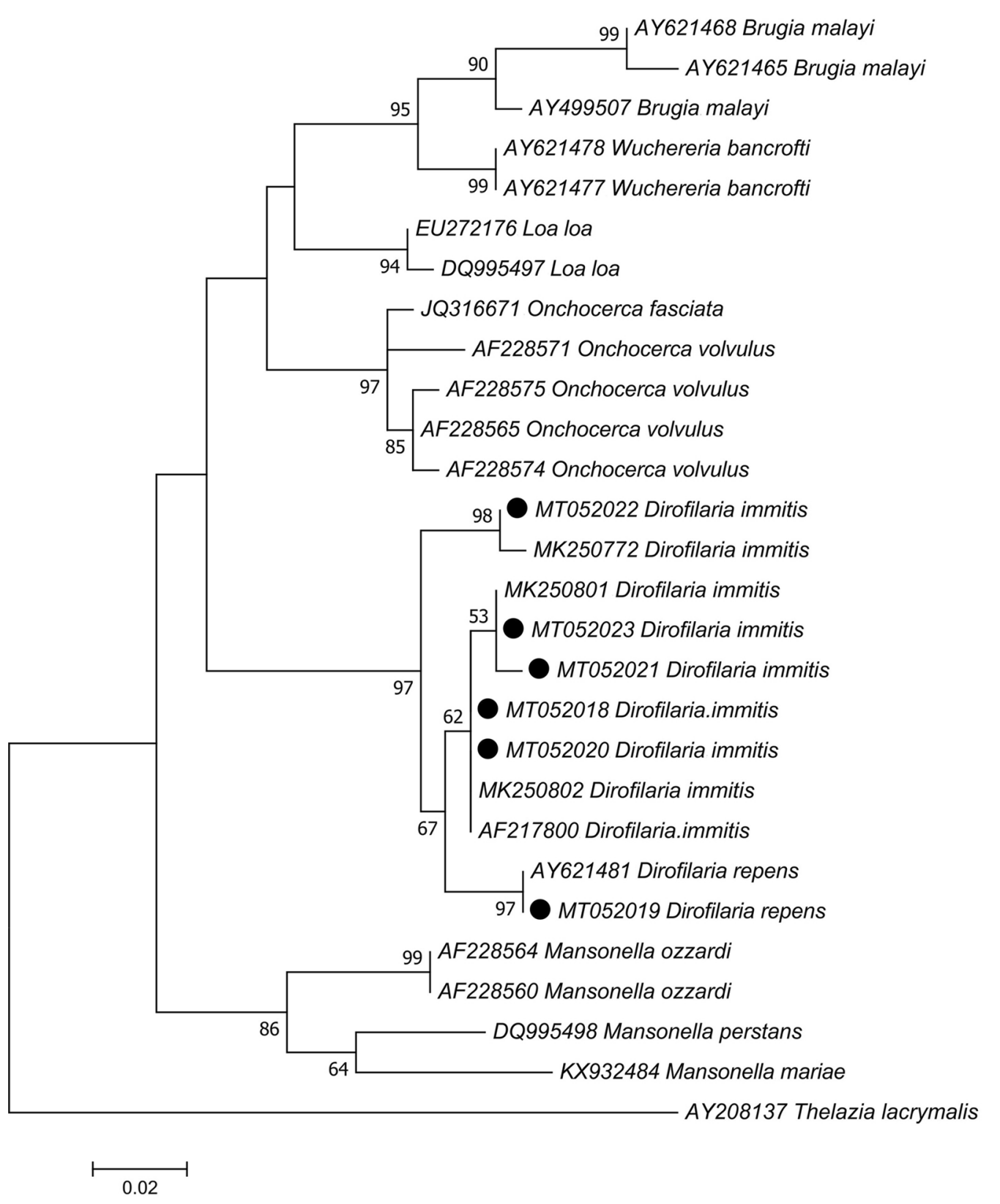

Fig. 1 Maximum likelihood tree showing the relationships between the 18S rDNA-ITS1 sequences obtained in this study (solid circles) and other filarial nematodes retrieved from GenBank. Thelazia lacrymalis was designated as outgroup. The numbers at the branch points are bootstrap values based on 1000 replicates. Bootstrap values less than $50 \%$ are hidden. The scale-bar measures evolutionary distance in substitutions per nucleotide

epidemiological features. Dirofilaria immitis is responsible for severe cardiopulmonary dirofilariasis, whereas D. repens causes non-pathogenic subcutaneous dirofilariasis in canids and felids. Accordingly, D. immitis and $D$. repens are globally regarded as human pulmonary and hypodermic/ophthalmic dirofilariasis, respectively $[28$, 29]. Herein we detected both nematodes in the study areas; however, their clinical manifestations need to be determined in detail in the future.

Successful development of the Dirofilaria species depends on an intermediate mosquito species and a vertebrate as a definitive host [30]. Many species of culicid mosquitoes in the genera Aedes, Anopheles, Armigeres, Coquillettidia, Culex, Culiseta, Mansonia and Psorophora 
Table 2 Identification of vertebrate hosts of the Simulium turgaicum complex based on the host cytb gene in ingested blood meals by multiplex and conventional PCR assays in the Aras River Basin, Iran

\begin{tabular}{|c|c|c|c|c|c|c|c|c|c|}
\hline \multirow[t]{3}{*}{ Village } & \multirow[t]{3}{*}{ Ecotope (No. of blood-fed specimens) } & \multirow{3}{*}{$\begin{array}{l}\text { No. of blood-fed } \\
\text { specimens in each } \\
\text { village }\end{array}$} & \multicolumn{2}{|c|}{ Multiplex PCR } & \multicolumn{5}{|c|}{ Host-specific PCR } \\
\hline & & & \multirow[t]{2}{*}{$n$} & \multirow[t]{2}{*}{ Hosts } & \multirow[t]{2}{*}{$n$} & \multicolumn{4}{|c|}{ Hosts } \\
\hline & & & & & & B & $\mathrm{H}$ & C & $\mathrm{D}$ \\
\hline Qarloujeh & $\begin{array}{l}\text { Humans/animals outdoors }(n=23) \text {; } \\
\text { irrigation canals }(n=14) \text {; lands along } \\
\text { the river }(n=17) ; \text { rice and alfalfa fields } \\
(n=19)\end{array}$ & 73 & 18 & $\begin{array}{l}\mathrm{DH}(n=1) ; \mathrm{CD}(n=2) ; \mathrm{BD}(n=2) ; \mathrm{CH} \\
\quad(n=9) ; \mathrm{BH}(n=2) ; \mathrm{BCD}(n=1) ; \mathrm{BCDH} \\
\quad(n=1)\end{array}$ & 73 & 7 & 37 & 13 & 16 \\
\hline Hamrahlou & Humans/animals outdoors $(n=2)$ & 2 & - & - & 2 & - & - & 2 & - \\
\hline Khetay & Humans/animals outdoors $(n=15)$ & 15 & 15 & $\begin{array}{l}\mathrm{H}(n=8) ; \mathrm{D}(n=1) ; \mathrm{DH}(n=2) ; \mathrm{CD}(n= \\
3) ; \mathrm{BCD}(n=1)\end{array}$ & 15 & 4 & 5 & 2 & 4 \\
\hline Gungormaz & Humans/animals outdoors $(n=13)$ & 13 & 11 & $\begin{array}{l}\mathrm{H}(n=4) ; \mathrm{CD}(n=2) ; \mathrm{BCD}(n=1) ; \mathrm{BDH}(n \\
\quad=2) ; \mathrm{CDH}(n=2)\end{array}$ & 13 & 4 & 4 & 3 & 2 \\
\hline Gholibaiglou & Humans/animals outdoors $(n=10)$ & 10 & 2 & $\mathrm{D}(n=1) ; \mathrm{BDH}(n=1)$ & 10 & - & 4 & 6 & - \\
\hline Total & & 113 & 46 & 46 & 113 & 15 & 50 & 26 & 22 \\
\hline
\end{tabular}

Abbreviations: B, bird; C, bovine; D, dog; $\mathrm{H}$, human

allow the development of both $D$. immitis and $D$. repens [31-55] which may transmit carrying worms to available vertebrates. Dirofilaria immitis, can parasitize many canines and felines in tropical, subtropical, and temperate regions worldwide [56]. However, filarial infections of dog, cat, fox, wolf, coyote, and least weasel by $D$. repens have been documented only in Old World countries [56]. Humans are not appropriate hosts for Dirofilaria spp.; however, among mammalian hosts, dogs are the most important reservoir host for human infection of both species of Dirofilaria [57].

Human and animal dirofilariasis has been documented in 11 of the 31 provinces of Iran. In two main foci of the country (southern regions of the Aras River: East Azerbaijan and Ardebil Provinces), the highest frequencies of dirofilariasis caused by $D$. immitis were $36.8 \%$ in dogs, $57.1 \%$ in jackals, $50 \%$ in foxes, $50 \%$ in wolves, and $0.8 \%$ in cats, and by $D$. repens, $60.8 \%$ in dogs and $10 \%$ in jackals $[48,58]$. Fourteen cases of human subcutaneous, ocular, testicular, and pulmonary dirofilariasis have been reported in the country [58]. The infective third-stage larvae of D. immitis and Setaria labiatopapillosa (Alessandrini) (Spirurida: Onchocercidae) were, respectively, reported in $C x$. theileri and $A n$. maculipennis [48].

Even if the presence of DNA of these parasites in the blackflies is suggestive, further studies are needed to demonstrate that blackflies are true vectors of $D$. immitis/D. repens. Simulium turgaicum (s.l.) was the most widespread blackfly in all ecotypes studied of the ten villages of Khoda-Afarin County. The Dirofilaria spp. infection rate in S. turgaicum (s.l.) (0.625\%) was significantly lower compared to those observed in culicid mosquitoes (0.85-10\%) [29]. These flies frequently feed on humans and dogs and potentially could pick up Dirofilaria spp. The possibility of blackflies as vectors of the Dirofilaria in this study is reinforced by studies showing that D. ursi Yamaguti, 1941 is transmitted by blackflies to black bears in North America and Japan [59, 60]. Likewise, in support of the vectorial activities of simuliids in Iran, a nodular eye lesion of human onchocerciasis caused by $O$. lupi and the involvement of blackflies in its transmission has been reported from center of the country [61].

Complex interactions between intrinsic and extrinsic factors influence vector competence. Intrinsic factors, such as genetics and physiology, as well as behavioral traits, may govern an insect's ability to acquire, support development, and transmit pathogenic agents. Extrinsic factors include the populations of the host reservoir and their activity patterns, climatic conditions, genetic variability in infectivity of pathogens, and even gut microorganisms [62-67]. Although blackflies are recognized as one of the most important medical and veterinary groups of arthropods due to their vector competence, there is a little information on their biology and ecology in Iran. This study is the first step for issuing public health policies and blackfly control campaigns in Iran, as well as those interested in studying the factors affecting vector eligibility.

Development of filarial nematodes to the third larval stage in the intermediate insect vector is essential for successful transmission to the definitive host. Microfilaria such as $D$. ursi develops to the third larval stage in the Malpighian tubules of the corresponding vector [68]. However, vector incrimination of blackflies relies on the 
presence of L3 worms in the head capsules of the female insects [68]. Future studies should be conducted to locate microfilariae in the Malpighian tubules and head capsules of the females of S. turgaicum (s.l.)

The literature shows that $D$. immitis and $D$. repens can infect many species of mammals varying in both quantity and quality [29]. Dissimilarity in susceptibility to parasites is common in multi-host, multi-parasite collections, and can have profound significance for ecology and evolution in these systems $[69,70]$. This may lead to heterogeneous and asymmetric transmission among and between host species [71-74]. The results of the present study show that insects other than Culicidae mosquitoes may be involved in establishing a cycle of dirofilariasis in the region. Since both $D$. immitis and $D$. repens can infect many species of mammals and can be transmitted by various vector species of mosquitoes and blackflies, they exhibit poor host specificity in terms of definitive and intermediate hosts [75]. These findings challenge our ability to recognize, forecast, and handle dirofilariasis dynamics in the region.

The results of this study revealed that S. turgaicum (s.l.) has diverse host preferences and feeds on humans, dogs, bovids and birds. A majority (69\%) of the specimens fed on humans and/or dogs. This may be related to host availability in the region and could have important epidemiological consequences. Dogs are the main reservoir of Dirofilaria spp., and if a blackfly prefers to feed on humans and dogs, then the probability of becoming infected and then transmitting the parasite to a human will be increased. However, to incriminate $S$. turgaicum (s.l.) as an actual vector of $D$. immitis and $D$. repens, more information on the biological and ecological factors that influence the transmission of these parasites in the studied region should be provided. These are included, but not limited to, parous rates, daily and seasonal fluctuations of biting activities (especially of parous females), preference for human body parts, longevity, flight range, and gonotrophic cycle [76].

\section{Conclusions}

Gathering site-specific information for vectors is a vital stage in implementation of vector control measures. Our study provides preliminary information on dirofilariasis in an active focus in northwestern Iran. We identified the dominant blackfly taxon in the study area and addressed issues of anthropophily and presence of Dirofilaira spp. in specimens with an empty abdomen. We are currently surveying nematode distributions in epidemiologically important parts of the bodies of blackflies. These findings could be used in epidemiological studies and strategic planning for the control of dirofilariasis in the region.

\section{Abbreviations}

18S rRNA: 18S Ribosomal RNA; cytb: Cytochrome b; ITS1: Internal transcribed spacer 1; s.l.: sensu lato.

\section{Acknowledgments}

We are grateful to Dr Peter H. Adler for his insightful suggestions and careful reading of the manuscript.

\section{Authors' contributions}

NMR and MAO conceived the study, its design and coordination. FK and SK participated in field work. FK identified the blackflies. FK and NMR carried out the molecular studies, sequence alignment and drafted the manuscript. MAO acquired resources. NMR and MAO supervised the analysis of the data and reformulated the manuscript. All authors read and approved the final manuscript.

\section{Funding}

The study was financially supported by the collaborative linkage grants awarded to NMR by the Pasteur Institute of Iran and to MAO by Tehran University of Medical Sciences (TUMS), Grant No. 39440.

\section{Availability of data and materials}

The datasets utilized in drawing the conclusions of this article are included in the article.

\section{Ethics approval and consent to participate}

Not applicable.

\section{Consent for publication}

Not applicable.

\section{Competing interests}

All authors declare that they have no conflicts of interest.

\section{Author details}

${ }^{1}$ Department of Plant Protection, Faculty of Agriculture, University of Tabriz, Tehran, Iran. ${ }^{2}$ Department of Parasitology, Pasteur Institute of Iran, Tehran, Iran. ${ }^{3}$ Research Center for Emerging and Reemerging Infectious Diseases, Pasteur Institute of Iran, Tehran, Iran. ${ }^{4}$ Department of Medical Entomology and Vector Control, School of Public Health, Tehran University of Medical Sciences (TUMS), Tehran, Iran.

Received: 22 June 2020 Accepted: 29 October 2020

Published online: 04 November 2020

\section{References}

1. Adler PH, Cheke RA, Post RJ. Evolution, epidemiology, and population genetics of black flies (Diptera: Simuliidae). Infect Genet Evol. 2010;10:846-65.

2. Adler PH, McCreadie JW. Black flies (Simuliidae). In: Mullen GR, Durden LA, editors. Medical and veterinary entomology. 3rd ed. San Diego: Elsevier; 2019. p. 237-59.

3. WHO. Onchocerciasis Fact Sheet. 2019. Geneva: World Health Organization; 2019. https://www.who.int/news-room/fact-sheets/detail/oncho cerciasis. Accessed 14 Jun 2019.

4. Klion AD, Nutman TB. Loiasis and Mansonella infections. In: Guerrant RL, Walker DH, Weller PF, editors. Tropical infectious diseases: principles, pathogens, \& practice. Philadelphia: Churchill Livingstone; 1999. p. $861-72$.

5. Shelley AJ, Coscaro'n S. Simuliid blackflies (Diptera: Simuliidae) and ceratopogonid midges (Diptera: Ceratopognidae) as vectors of Mansonella ozzardi (Nematoda: Onchocercidae) in northern Argentina. Mem Inst Oswaldo Cruz. 2001;96: 451-8.

6. Bobrova SI. Swarming of bloodsucking blackflies (Diptera, Simuliidae) in Siberia. Parazitologiya. 1977;11:442-5. 
7. Adler PH, McCreadie JW. Insect life: the hidden ecology of black flies: sibling species and ecological scale. Am Entomol. 1997:43:153-62.

8. Sariözkan S, Inci A, Yildirim A, Düzlü O, Gray EW, Adler PH. Economic losses during an outbreak of Simulium (Wilhelmia) species (Diptera: Simuliidae) in the Cappadocia Region of Turkey. Turk Parazitol Dergisi. 2014;38:116-9.

9. Khanzadeh F, Khaghaninia S, Maleki-Ravasan N, Oshaghi MA, Adler PH. Black flies (Diptera: Simuliidae) of the Aras River Basin: species composition and floral visitation. Acta Trop. 2020:105536:1-8.

10. Tabatabaei F, Azarmi S, Afshar MJ, Yarizadeh H, Mohtasebi S. Blackfly fever and dermatitis caused by Simulium kiritshenkoi: a human case report in Iran. BMC Infect Dis. 2020;20:348

11. Ames IA. lowa insect information notes. Ames: Department of Entomology, lowa State University, Academic Press; 2005.

12. Schnellbacher RW, Holder K, Morgan T, Foil L, Beaufrère H, Nevarez J, et al. Avian simuliotoxicosis: outbreak in Louisiana. Avian Dis. 2012;56:616-20.

13. Adler PH. World blackflies (Diptera: Simuliidae): a comprehensive revision of the taxonomic and geographical inventory. 2020. p. 142. https://biomi a.sites.clemson.edu/pdfs/blackflyinventory.pdf. Accessed 1 Jan 2020.

14. Crosskey RW. The natural history of blackflies. London: The British Museum of Natural History; 1990.

15. Werner D, Adler PH. A faunistic review of the black flies (Simuliidae, Diptera) of the federal state of Sachsen-Anhalt. Germany Abhandl Berichte Naturk. 2005;27:205-45.

16. Inci A, Yildirim A, Duzlu O, Onder Z, Ciloglu A, Seitz G, et al. Genetic diversity and identification of palearctic black flies in the subgenus Wilhelmia (Diptera: Simuliidae). J Med Entomol. 2017;54:888-94.

17. Đuknić J, Jovanović V, Popović N, Živić I, Raković M, Čerba D, Paunović M. Phylogeography of Simulium subgenus Wilhelmia (Diptera: Simuliidae) Insights from Balkan populations. J Med Entomol. 2019;56:967-78.

18. Adler PH, Inci A, Yildirim A, Duzlu O, McCreadie JW, Kúdela A, et al. Are black flies of the subgenus Wilhelmia (Diptera: Simuliidae) multiple species or a single geographical generalist? Insights from the macrogenome. Biol J Linn Soc. 2015;114:163-83.

19. Michalski ML, Bain O, Fischer K, Fischer PU, Kumar S, Foster JM. Identification and phylogenetic analysis of Dirofilaria ursi (Nematoda: Filarioidea) from Wisconsin black bears (Ursus americanus) and its Wolbachia endosymbiont. J Parasitol. 2010:96:412-9.

20. Crosskey RW. A taxonomic account of the blackfly fauna of Iraq and Iran including keys for species identification (Diptera: Simuliidae). J Nat Hist. 2002;36:1841-86.

21. Collins FH, Mendez MA, Rasmussen MO, Mehaffey PC, Besansky NJ, Finnerty V. A ribosomal RNA gene probe differentiates member species of the Anopheles gambiae complex. Am J Trop Med Hyg. 1987;37:37-41.

22. Tang TT, López-Vélez R, Lanza M, Shelley AJ, Rubio JM, Luz SLB. Nested PCR to detect and distinguish the sympatric filarial species Onchocerca volvulus, Mansonella ozzardi and Mansonella perstans in the Amazon region. Mem Inst Oswaldo Cruz. 2010;105:8238.

23. Kumar S, Stecher G, Li M, Knyaz C, Tamura K. Mega X: molecular evolutionary genetics analysis across computing platforms. Mol Biol Evol. 2018:35:1547-9.

24. Lahiff S, Glennon M, O'Brien L, Lyng J, Smith T, Maher M, Shilton N. Species-specific PCR for the identification of ovine, porcine and chicken species in meat and bone meal (MBM). Mol Cell Probes. 2001;15:27-35.

25. Parodi B, Aresu O, Bini D, Lorenzini R, Schena F, Visconti P, Cesaro M, Ferrere MD, Andreotti V, Ruzzon T. Species identification and confirmation of human and animal cell lines: a PCR-based method. Biotechniques. 2002:32:432-40.

26. Ngo KA, Kramer LD. Identification of mosquito blood meals using polymerase chain reaction (PCR) with order-specific primers. J Med Entomol. 2003:40:215-22

27. Chang MC, Teng HJC, Chen F, Chen YC, Jeng CR. The resting sites and blood-meal sources of Anopheles minimus in Taiwan. Malar J. 2008:7:105-12.

28. Anderson RC. Nematode parasites of vertebrates. Their development and transmission. Wallingford: CABI Publishing: 2000.

29. Simón F, Siles-Lucas M, Morchón R, González-Miguel J, Mellado I, Carretón E, et al. Human and animal dirofilariasis: the emergence of a zoonotic mosaic. Clin Microbiol Rev. 2012;25:507-44.
30. Capelli G, Regalbono A, Simonato G, Cassini R, Cazzin S, Cancrini G, et al. Risk of canine and human exposure to Dirofilaria immitis infected mosquitoes in endemic areas of Italy. Parasit Vectors. 2013;6:60

31. Silaghi C, Beck R, Capelli G, Montarsi F, Mathis A. Development of Dirofilaria immitis and Dirofilaria repens in Aedes japonicus and Aedes geniculatus. Parasit Vectors. 2017;10:94

32. Russell RC, Webb CE, Davies N. Aedes aegypti (L.) and Aedes polynesiensis Marks (Diptera: Culicidae) in Moorea, French Polynesia: a study of adult population structures and pathogen (Wuchereria bancrofti and Dirofilaria immitis) infection rates to indicate regional and seasonal epidemiological risk for dengue and filariasis. J Med Entomol. 2005;42:1045-56.

33. Licitra B, Chambers EW, Kelly R, Burkot TR. Detection of Dirofilaria immitis (Nematoda: Filarioidea) by polymerase chain reaction in Aedes albopictus, Anopheles punctipennis, and Anopheles crucians (Diptera: Culicidae) from Georgia, USA. J Med Entomol. 2010;47:634-8.

34. Russell RC, Geary MJ. The influence of microfilarial density of dog heartworm Dirofilaria immitis on infection rate and survival of Aedes notoscriptus and Culex annulirostris from Australia. Med Vet Entomol. 1996;10:29-34

35. Loftin KM, Byford RL, Loftin MJ, Craig ME. Potential mosquito vectors of Dirofilaria immitis in Bernalillo County, New Mexico. J Am Mosq Control Assoc. 1995;11:90-3.

36. Cancrini G, Magi M, Gabrielli S, Arispici M, Tolari F, Dell'Omodarme M, Prati MC. Natural vectors of dirofilariasis in rural and urban areas of the Tuscan region, central Italy. J Med Entomol. 2006;43:574-9.

37. Cancrini G, Kramer L. Insect vectors of Dirofilaria spp. In: Simon F, Genchi $C$, editors. Heartworm infection in humans and animals. Ediciones Universidad de Salamanca, Salamanca: Spain; 2001. p. 63-82.

38. Labarthe N, Serrão ML, Melo YF, de Oliveira SJ, Lourenço-de-Oliveira R. Potential vectors of Dirofilaria immitis (Leidy, 1856) in Itacoatiara, oceanic region of Niterói municipality, State of Rio de Janeiro. Brazil Mem Inst Oswaldo Cruz. 1998:93:425-32.

39. Scoles GA, Dickson SL, Blackmore MS. Assessment of Aedes sierrensis as a vector of canine heartworm in Utah using a new technique for determining the infectivity rate. J Am Mosq Control Assoc. 1993;9:88-90.

40. Manrique-Saide P, Escobedo-Ortegón J, Bolio-González M, Sauri-Arceo C, Dzib-Florez S, Guillermo-May G, et al. Incrimination of the mosquito Aedes taeniorhynchus, as the primary vector of heartworm, Dirofilaria immitis, in coastal Yucatan, Mexico. Med Vet Entomol. 2010;24:456-60.

41. Debboun M, Green TJ, Rueda LM, Hall RD. Relative abundance of tree hole-breeding mosquitoes in Boone County, Missouri, USA, with emphasis on the vector potential of Aedes triseriatus for canine heartworm, Dirofilaria immitis (Spirurida: Filariidae). J Am Mosq Control Assoc. 2005:21:274-8

42. Yildirim A, Inci A, Duzlu O, Biskin Z, Ica A, Sahin I. Aedes vexans and Culex pipiens as the potential vectors of Dirofilaria immitis in Central Turkey. Vet Parasitol. 2011:178:143-7.

43. Montarsi F, Ciocchetta S, Devine G, Ravagnan S, Mutinelli F, Regalbono A, et al. Development of Dirofilaria immitis within the mosquito Aedes (Finlaya) koreicus, a new invasive species for Europe. Parasit Vectors. 2015;8:177.

44. Ferreira CAC, de Pinho MV, Lourenço MT, Novo M, Palmeiro Calado MM, Pires Gonçalves $L A$, et al. First molecular identification of mosquito vectors of Dirofilaria immitis in continental Portugal. Parasit Vectors. 2015:8:139.

45. Shaikevich E, Bogacheva A, Ganushkina L. Dirofilaria and Wolbachia in mosquitoes (Diptera: Culicidae) in central European Russia and on the Black Sea coast Parasite 2019:26:2.

46. Theis JH, Kovaltchouk JG, Fujioka KK, Saviskas B. Vector competence of two species of mosquitoes (Diptera: Culicidae) from southern California for Dirofilaria immitis (Filariidea: Onchocercidae). J Med Entomol. 2000;37:295-7.

47. Ahid SM, Lourenço-De-Oliveira R. Mosquitoes potential vectors of canine heartworm in the Northeast Region from Brazil. Rev Saude Publica. 1999:33:560-5

48. Azari-Hamidian S, Yaghoobi-Ershadi MR, Javadian E, Abai MR, Mobedi I, Linton YM, et al. Distribution and ecology of mosquitoes in a focus of dirofilariasis in northwestern Iran, with the first finding of filarial larvae in naturally infected local mosquitoes. Med Vet Entomol. 2009;23:111-21. 
49. Todorovic S, McKay T. Potential mosquito (Diptera: Culicidae) vectors of Dirofilaria immitis from residential entryways in Northeast Arkansas. Vet Parasitol. 2020;109105:1-6.

50. Watts KJ, Courtney CH, Reddy GR. Development of a PCR- and probebased test for the sensitive and specific detection of the dog heartworm Dirofilaria immitis, in its mosquito intermediate host. Mol Cell Probes. 2001;14:425-30

51. Coluzzi M, Cancrini G. Genetics of the suceptibility of Aedes aegypti to Dirofilaria repens. Parasitologia. 1974;16:239-56.

52. Cancrini G, Pietrobelli M, Regalbono AF, Tampieri MP, Torre A. Development of Dirofilaria and Setaria nematodes in Aedes albopictus. Parasitologia. 1995;37:141-5.

53. Fuelleborn F. Uber Versuche an hundefilarien und deren Uber-tragung durch Mücken. Arc Sciffs Tropenbyg. 1908;12:309.

54. Gunewardene K. Observations on the development of Dirofilaria repens in Aedes (Stegomyia) albopictus and other common mosquitoes of Ceylon. Ceylon J Med Sci. 1956;9:45-53.

55. Bernard NP, Bauche J. Conditions de propagation de la filariose souscutanée du chien Stegomyia fasciata hote intermédiaire de Dirofilaria repems. Bull Soc Pathol Exot. 1913;2:89-99.

56. Otranto D, Deplazes P. Zoonotic nematodes of wild carnivores. Int J Parasitol Parasites Wildl. 2019;9:370-83.

57. McCall JW, Genchi C, Kramer LH, Guerrero J, Venco L. Heartworm disease in animals and humans. Adv Parasitol. 2008;66:193-285.

58. Azari-Hamidian S, Yaghoobi-Ershadi MR, Javadian E, Mobedi I, Abai MR. Review of dirofilariasis in Iran. J Med Fac Guilian Univ Med Sci. 2007:15:102-13.

59. Yokohata Y, Fujita O, Kamiya M, Fujita T, Kaneko K, Ohbayashi M. Parasites from the Asiatic black bear (Ursus thibetanus) on Kyushu Island, Japan. J Wildl Dis. 1990;26:137-8

60. Duffy MS, Greaves TA, Burt MDB. Helminths of the black bear, Ursus americanus, in New Brunswick. J Parasitol. 1994;80:478-80.

61. Mowlavi G, Farzbod F, Kheirkhah A, Mobedi I, Bowman DD, Naddaf SR. Human ocular onchocerciasis caused by Onchocerca lupi (Spirurida, Onchocercidae) in Iran. J Helminthol. 2013;88:250-5.

62. Beerntsen BT, James AA, Christensen BM. Genetics of mosquito vector competence. Microbiol Mol Biol Rev. 2000;64:115-37.

63. Lefe'vre T, Vantaux A, Dabire KR, Mouline K, Cohuet A. Non-genetic determinants of mosquito competence for malaria parasites. PLOS Pathog. 2013;9:1003365.

64. Maleki-Ravasan N, Oshaghi MA, Afshar D, Arandian MH, Hajikhani S, Akhavan AA, et al. Aerobic bacterial flora of biotic and abiotic compartments of a hyperendemic zoonotic cutaneous leishmaniasis (ZCL) focus. Parasit Vectors. 2015;8:63.
65. Goddard J. Infectious diseases and arthropods. 3rd ed. In: Georgiev VS, Series editor. Infectious Diseases: Springer, Switzerland; 2018. p. 33-4.

66. Karimian F, Vatandoost H, Rassi Y, Maleki-Ravasan N, Mohebali M, Shirazi $\mathrm{MH}$, et al. Aerobic midgut microbiota of sand fly vectors of zoonotic visceral leishmaniasis from northern Iran, a step toward finding potential paratransgenic candidates. Parasit Vectors. 2019;12:10.

67. Choubdar N, Oshaghi MA, Rafinejad J, Pourmand MR, Maleki-Ravasan $\mathrm{N}$, Salehi-Vaziri M, et al. Effect of meteorological factors on Hyalomma species composition and their host preference, seasonal prevalence and infection status to Crimean-Congo Haemorrhagic Fever in Iran. J Arthropod Borne Dis. 2019;30:268-83.

68. Addison EM, Transmission of Dirofilaria ursi Yamaguti, . Nematoda: Onchocercidae) of black bear (Ursus americanus) by blackflies (Simuliidae. Can J Zool. 1941;1980(58):1913-22.

69. Hatcher MJ, Dick JTA, Dunn AM. How parasites affect interactions between competitors and predators. Ecol Lett. 2006:9:1253-71.

70. Barrow LN, McNew SM, Mitchell N, Galen SC, Lutz HL, Skeen H, et al. Deeply conserved susceptibility in a multi- host, multi-parasite system. Ecol Lett. 2019;22:987-98.

71. Woolhouse MEJ, Taylor LH, Haydon DT. Population biology of multihost pathogens. Science. 2001;292:1109-12.

72. Power AG, Mitchell CE. Pathogen spillover in disease epidemics. Am Nat. 2004;164(Suppl. 5):79-89.

73. Rigaud T, Perrot-Minnot MJ, Brown MJF. Parasite and host assemblages: embracing the reality will improve our knowledge of parasite transmission and virulence. Proc R Soc B. 2010;277:3693-702.

74. Fenton A, Streicker DG, Petchey OL, Pedersen AB. Are all hosts created equal? Partitioning host species contributions to parasite persistence in multihost communities. Am Nat. 2015;186:610-22.

75. Barriga OO. Dirofilariasis. In: Steele JH, Schultz MG, editors. Handbook series in zoonoses, vol. 2. CRC Press Inc, Boca Raton: FL; 1982. p. 93-110.

76. Takaoka H. Review of the biology and ecology of adult blackflies in relation to the transmission of onchocerciasis in Guatemala. Trop Med Health. 2015;43:71-85.

\section{Publisher's Note}

Springer Nature remains neutral with regard to jurisdictional claims in published maps and institutional affiliations.
Ready to submit your research? Choose BMC and benefit from:

- fast, convenient online submission

- thorough peer review by experienced researchers in your field

- rapid publication on acceptance

- support for research data, including large and complex data types

- gold Open Access which fosters wider collaboration and increased citations

- maximum visibility for your research: over 100M website views per year

At $B M C$, research is always in progress.

Learn more biomedcentral.com/submissions 